\title{
Implementation of The Tiered Supervision as a Supervision Function
}

\section{Retno Wahyu Nugrahini1,2, Vivi Yosafianti Pohan²}

${ }^{1}$ Rumah Sakit Islam Sultan Agung Semarang, Indonesia

2 Universitas Muhammadiyah Semarang, Indonesia

\section{Article Info}

\section{Article History: \\ Accepted March 4th, 2020}

\section{Keywords:}

Nursing Supervision; Nursing Management; Supervision Function

\section{INTRODUCTION}

Nursing management is a process of planning, organizing, managing staff, directing, supervising and controlling each other. The role of the nursing manager cannot be separated from the management process carried out, including applying attention to material resources and nursing human resources. The role of the manager that is actually applied is able to bring transformation for other nursing staff to apply nursing quality standards. Standards

\section{Abstract}

Tiered supervision that supports improving the quality of nursing services in the field of nursing at Sultan Agung Islamic Hospital has not been carried out in a structured and documented manner. Baitul Izzah 1 room as a disease treatment room in class III, the head of the room has not yet supervised the Person in Charge of Care (PPJA) and so on PPJA to the Associate Nurse (PP). The supervision that has been carried out so far is only to ask directly about existing problems to the head of the room and directly observe the activities of implementing nursing care by PPJA and PP. Tiered supervision does not go well, because there are no references and standards for its implementation. The purpose of this study was to determine Implementation of The Tiered Supervision as a Supervision Function. It was found that the implementation of tiered supervision instruments improved the performance of the head of the room, PPJA and PP, then the patient's medical record document increases in completeness chargingespecially the patient's Islamic education document. In conclusion, tiered supervision instruments are very helpful in the implementation of the supervisory function as well as monitoring and evaluation in nursing management in the mplementation of nursing care in the inpatient room. The recommendation for the role of the nursing field that is most important in controlling the quality of nursing care is to actively involve staff to jointly ensure the continuity of the implementation of tiered nursing supervision.

\section{Corresponding author:}

Retno Wahyu Nugrahini

are set to measure the performance of objective, measurable and achievable nursing care and services. ${ }^{1}$

The nursing management process is carried out with an open systems approach, where each component is interconnected, which includes input, process, output, control and feedback. Nursing managers are required to plan (plan), organize (organize), lead and evaluate (evaluate) the facilities and infrastructure available to be able to provide nursing care that is as effective and 
efficient as possible for individuals, families and communities. ${ }^{2}$

Supervision or controling is the application of methods and tools to ensure that the plan has been implemented according to what has been determined. Supervision through communication, namely supervising and communicating directly with the team leader and executor regarding the nursing care provided to patients. Supervision in nursing management through supervision with direct and indirect supervision.

Nursing supervision is a supervision and guidance activity carried out continuously by supervisors covering nursing service problems, manpower and equipment problems so that patients receive quality service at all times. $^{3}$ Supervision or controling is the application of methods and tools to ensure that the plan has been implemented according to what has been determined. Supervision through communication, namely supervising and communicating directly with the team leader and executor regarding the nursing care provided to patients. Supervision in nursing management through supervision with direct and indirect supervision.

Tiered nursing supervision at Sultan Agung Islamic Hospital in Semarang has not been implemented. The head of the nursing department carries out supervision of the head of the room in completing his duties, only asking things that have problems in the treatment room. The head of the room in monitoring and evaluating PPJA's duties in providing nursing care to patients does not have standardized tools or references, as well as PPJA evaluating PPJA is not well documented. The absence of supervision through supervision from nursing management, the head of the room and PPJA in a documented and structured manner so that the evaluation cannot be carried out continuously because there are no records used as evaluation material.
The supervision instrument as a reference in the implementation of tiered supervision as a form of supervision activities, if it is carried out and documented in a structured manner and there is a clear supervision assessment format, the supervisory function will run smoothly.

The assessment format is the nurse's performance record for further improvement and the supervised nurse will also have a performance record as material for self-evaluation. Thus it will be easy to make improvement efforts in nursing services. However, if the supervision activities are not carried out in a structured and well-documented manner and there is no evaluation format for standard supervision, then the form of evaluation that is carried out cannot be carried out continuously because there are no notes used as material for a structured evaluation. ${ }^{4}$

The purpose of this research is to find out the extent of the supervisory function of nursing management through tiered supervision, providing solutions by making supervision instruments and evaluating the implementation of supervision instruments at Sultan Agung Islamic Hospital Semarang.

Increased supervision by the head of the room, the nursing committee, and the nursing department needs to be improved, by means of an organizational structure approach in order to motivate the performance of the nurse executing. ${ }^{5}$ The importance of clinical supervision apart from managerial supervision is therefore, that an effective clinical surveillance support system is strengthened to support managerial supervision. ${ }^{6}$

The purpose of this study was to determine Implementation of The Tiered Supervision as a Supervision Function.

\section{METHODS}


The research design uses descriptive qualitative methods, namely the research method is basically a scientific way to obtain data with specific purposes and uses as well as to determine how to find, collect, process and analyze research data. ${ }^{7}$ The method was chosen to obtain natural data about the understanding of the supervisory function through tiered supervision and its implementation using the supervision instrument through interviews.

\section{RESULTS}

Assessment according to the priority of the problem in the Baitu Izzah 1 room obtained 2 (two) problems, namely: the frequency of Islamic education with the number of 96 , and the number of 256 tiered nursing supervision activities that have not been implemented. tiered. Tiered supervision activities have not been carried out because there is no reference for implementation, so that the completion of routine work has no target. Supervision is a coaching activity that is planned to assist nursing personnel in doing their job effectively. ${ }^{8}$

The intervention was carried out by conducting socialization on nursing supervision, making supervision instruments, and making supervision of Standard Operating Procedures (SOP). Socialization about supervision material with Focus Group Discussion (FGD), Socialization carried out directly to the Head of Nursing, Head of Department of Education, PPJA and PP continued with the implementation of supervision instruments on December 9, 2020. Tiered supervision instruments can be implemented properly from the field of nursing, Head of Department and PPJA well .. Group clinical supervision as an intervention to support nurse resilience in the hospital as a recommendation for practice, to improve development through clinical supervision. ${ }^{9}$

Evaluation of the implementation of tiered supervision instruments by conducting interviews and observations to three participants, namely the Head of Nursing, the Head of the Room and the PPJA.

.... With the supervision instrument it makes it easier for me to monitor the memnitor of the head of the room... "(P1)

.... This supervision instrument turned out to make it easier to complete supervisory tasks for PPJA and my duties as head of the room .. $(P 2)$

....After there are supervision instruments, all of which become my job as PPJA to monitor and evaluate $P P$ in providing nursing care to be better and more directed.... . (P3)

Observations are made by looking at the filling of the supervsisi instrument. The supervision instruments are well implemented and fully stocked. Clinical nursing supervision has an influence on nurses' experiences of well-being and in relation to their psychosocial work environment. Nurses attending clinical nursing supervision reported increased satisfaction with their psychosocial work environment 10

\section{DISCUSSION}

The supervisory function will run well with the implementation of supervision. Tiered supervision is carried out as an effort to observe and monitor the implementation of nursing management or the provision of nursing care on an ongoing basis including nursing service problems, workforce problems, and care so that patients receive quality service at all times. ${ }^{2}$ Based on the evaluation of the implementation of tiered supervision through the supervsisi instrument, the performance of the head of the room, PPJA and PP is different from the previous one which was seen only providing routine nursing care. Supervision of the head of the room has a positive and significant effect on nurse performance. This means that the better the supervision of the head of the room, the nurse's performance will increase. Conversely, the 
less good the supervision of the head of the room, the lower the performance of the nurse. Supervision of the head of the room, workload, and motivation simultaneously (together) have a significant effect on the performance of nurses. This means that the better the supervision of the head of the room, workload, and motivation together, the nurse's performance will increase. On the other hand, the supervision of the head of the room is not good. ${ }^{11}$

Completeness of the documentation found in the second priority problem is the Islamic education medical record document, with the implementation of supervision, it is hoped that it can be completely filled.Existencesupervision by documenting nursing care indicates that the need for supervision action for hospitals that have not implemented supervision and for hospitals that have implemented supervision is expected to further improve the implementation of the supervision. Because with this supervision, a nurse will feel that someone is accompanying her and this will have a positive impact on the nurse's own performance. ${ }^{12}$

The description of the supervision of the head of the room that is perceived by the nurse states and the description of how $53 \%$ of the nursing care documents are completely filled. A good head of the room increases the documentation of nursing care so that the head of the room should carry out the supervision properly and schedule to continue to improve the quality of nursing care documents. ${ }^{13}$

In Asmawati's research, Yuanita Ananda, Alkafi (2018), in her research it can be concluded that from 12 nurse respondents before being given supervision, the average development of nursing care documentation was 34.56 with a standard deviation of 4,912 . Furthermore, it appears that the minimum value of 20 is classified as incomplete documentation and the maximum value of 32 is classified as complete documentation. Of the 12 nurse respondents after being given supervision, the average development of documentation of nursing care was 28.38 with a standard deviation of 4.773. Furthermore, it can be seen that the minimum value of 21 is classified as complete documentation and the maximum value of 38 is classified as complete documentation. There is a difference in documenting nursing care before and after being given supervision with a $P$ value of $0,000.14$

Supervision or supervision material is adjusted to the job descriptions of each supervised nursing staff. For the head of the room, supervision material includes managerial skills and nursing care. The team leader is supervised regarding team management skills and the ability to provide nursing care. Implementing nurses undergo supervision related to the ability of nursing care carried out.

Some of the activities that can be supervised by the person in charge of the room / head of the room for the orphans are:

a. Conducting pre conference and post conference

b. Implementation of patient consideration

c. Implementation of nursing assessments

d. Implementation of nursing diagnoses

e. Implementation of nursing plans

f. Implementation of nursing implementation

g. Implementation of nursing evaluation

h. Implementation of nursing care documentation

i. Implementation of universal precautions

j. Implementation of patient safety

$\mathrm{k}$. Implementation of case reflection discussions

1. Implementation of discharge planning

m. Compliance with SPO

n. Implementation of the nursing round 
Some of the activities that can be supervised by the orphan of the implementing nurses are:
a. Implementation of nursing care for patients
b. Implementation of nursing care documentation
c. Compliance with SPO
d. Implementation of universal precautions
e. Implementation of patient safety

Nursing interventions are oriented towards 14 (fourteen) basic nursing components including:
a. Meet the needs of oxygen.
b. Meet the needs of nutrition, fluid and electrolyte balance
c. Meet the needs of elimination.
d. Meet security needs.
e. Meet the needs of cleanliness and physical comfort.
f. Meet the needs of rest and sleep.
g. Meet the needs of movement and physical activity.
h. Meet spiritual needs.
i. Meet emotional needs.
j. Meet communication needs
k. Prevent and overcome physiological reactions.
l. Meet medical needs and help the healing process.
m. Meet extension needs.
n. Meet rehabilitation needs

Supervision in hospital hospital accreditation is also an element in the assessment, as a basis for monitoring evidence of implementation, namely at

\section{Access to Hospitals and Service Continuity (AHSC)}

In Access to Hospitals and Service Continuity (AHSC) 3.3, it is stated "If the patient is in the management of the patient service manager (MPS), the continuity of the above process is monitored, followed, and the transfer is supervised by the patient service manager (MPS)".

\section{Competence and Authority of Staff (CAS)}

In Staff Competency and Authority (CAS) 5, it is stated that "All staff are supervised and evaluated periodically to ensure continuity of competence in their position".

\section{Hospital Governance (HG).}

a. In Hospital Governance (HG) 8.6. stated "The organizational structure can support the control process on the quality of clinical services".

b. In Hospital Governance (HG) 11, it is stated that "the head of the service unit improves the quality and safety of patients by participating in the quality improvement and patient safety program of the hospital, monitoring, and improving specific patient care in his unit. The head of the service unit involves all his staff in quality improvement and patient safety activities that reflect the overall priorities of the hospital and conducts monitoring of clinical and non-clinical activities specific to the service unit ". 15

Theory Conformity: Supervision is a professional process carried out by supervisors through a continuous process of direction, guidance and evaluation to supervisees (supervisory participants) to increase the ability of supervisees in carrying out their work in order to achieve professional service quality and protection of patient safety.

Nursing management activities will run well and improve service quality by approaching management functions must always be carried out optimally, including planning, organizing, directing, and controlling (monitoring and evaluation). Nursing service management focuses on the $5 \mathrm{M}$ components (Man, Money, Material, 
Method, Machine). In every management activity, it always begins with planning and ends with control which is a recurring cycle.

\section{CONCLUSION}

The results of the evaluation of the implementation of the supervision instrument are very helpful in the implementation of tiered supervision in the nursing management of Sultan Agung Islamic Hospital Semarang. The implementation of nursing leveled supervision is quite effective in increasing the insight in the field of nursing, the Head of Runag, PPJA and PP. A good perception from the Head of the Room about the importance of nursing clinical supervision is a good initial capital to make changes and improvements in carrying out its functions. This supervisory function requires hospital support in its implementation.

The recommended suggestion is that the role of nursing is most important in controlling the quality of nursing care is to actively involve staff to jointly ensure the continuity of the application of nursing leveled supervision. Development into an online application is the task of the nursing field.

\section{ACKNOWLEDGMENTS}

Special thanks to Dr. Ms. Vivi Yosafianti Pohan, M.Kep for their guidance and motivation in completing this task. may Allah bestow good deeds and blessings.

\section{CONFLICTS OF INTEREST}

Neither of the authors has any conflicts of interest that would bias the findings presented here.

\section{REFERENCES}

1. Julianto M. Peran dan fungsi manajemen keperawatan dalam manajemen Konflik. Fatmawati Hosp J. Published online 2016:1-7.
2. Nursalam. Manajemen Keperawatan: Aplikasi Dalam Praktik Keperawatan Profesional. 5th ed. Salemba Medika; 2015.

3. Marquis B, Huston C. Kepemimpinan dan Manajemen Keperawatan Teori \& Aplikasi. Manag Keperawatan. Published online 2010.

4. Nursalam. Manajemen Keperawatan Aplikasi dalam Praktik Nursalam. (2011). Manajemen Keperawatan Aplikasi dalam Praktik Keperawatan Profesional Edisi 3. Salemba Medika.

https://doi.org/10.1001/archinte.165.22.2659 Keperawatan Profesional Edisi 3. Salemba Medika. 2011.

5. Zahara Y, Sitorus R, Sabri L. Faktor-faktor Motivasi Kerja: Supervisi, penghasilan dan hubungan interpersonal. J Keperawatan Indones. 2011;14(2011):73-82.

6. Cutcliffe JR, Hyrkäs K. Multidisciplinary attitudinal positions regarding clinical supervision: A cross-sectional study. J Nurs Manag. Published online 2006. doi:10.1111/j.1365-2934.2006.00720.x

7. Sugiyono. Metode Penelitian Kuantitatif Kualitataif dan Kombinasi (Mixed Methods). J Chem Inf Model. Published online 2016.

8. Cope V, Murray M. Leadership styles in nursing. Nurs Stand. Published online 2017. doi:10.7748/ns.2017.e10836

9. Francis A, Bulman C. In what ways might group clinical supervision affect the development of resilience in hospice nurses? Int J Palliat Nurs. Published online 2019. doi:10.12968/ijpn.2019.25.8.387

10. Bégat I, Severinsson E. Reflection on how clinical nursing supervision enhances nurses' experiences of well-being related to their psychosocial work environment. J Nurs Manag. Published online 2006. doi:10.1111/j.13652934.2006.00718.x

11. Hastuti AT. Hubungan persepsi perawat pelaksana tentang kemampuan supervisi kepala ruang dengan kinerja perawat di instalasi rawat inap rumah umum daerah kota semarang. FIKKes J Keperwatan. Published online 2014.

12. Publikasi N, Studi P, Keperawatan I, Kedokteran F, Tanjungpura U. Hubungan supervisi dengan pendokumentasian asuhan keperawatan di ruang rawat inap rumah sakit tk ii kartika husada kubu raya. Published online 2017.

13. Alidosti M, Delaram M, Dehgani L, Maleki Moghadam M. Relationship Between SelfEfficacy and Burnout Among Nurses in Behbahan City, Iran. Women's Heal Bull. Published online 2016. doi:10.17795/whb- 
30445

14. ananda yuanita, Asmawati A, Alkafi A. Pengaruh Supervisi Kepala Ruangan Terhadap Pelaksanaan Pendokumentasian Asuhan Keperawatan Di Ruang Rawat Inap RSU Aisyiyah Padang Tahun 2018. JIK- J ILMU
Kesehat. doi:10.33757/jik.v2i2.125

2018;2(2):108-112.

15. KARS. Standar Nasional Akreditasi Rumah Sakit (SNARS). 1.1. Komisi Akreditasi Rumah Sakit; 2019. 